\title{
BRIEF ACCOUNT OF THE STATUS OF THE COMMON RAVEN (Corvus corax) IN THE CARROT RIVER VALLEY, 1919-1958
}

By Maurice Street, Nipawin, Sask.

I remember seeing my first ravens, a single pair, a mile or two. southwest of Tisdale, Sask., during the early summer of 1919. Earlier that year my brother, Stanley, had found their nest in a very tall spruce. From this nest he collected one egg to add to his collection of eggs started in England some 10 or more years earlier. (At that time, in England, it was a common practice for school boys to collect birds' eggs as a pastime.) Now this raven's egg, after nearly 40 years, is still in his possession and still in perfect condition. Much larger than the egg of the Common Crow, it is very similar in colour. My brother considered the raven's nest quite a find as the raven was a very rare bird in the TisdaleNipawin area then. In fact, it was not until the early 1930's that I saw my next ravens, this time a few miles east of Cudeive. From then on ravens were seen with increasing frequency, and by the mid 1940's, especially along the Saskatchewan River, on bright clear days in autumn or laite fall, numbers could be seen soaring endlessly back and forth over the river obviously taking advantage $\mathrm{ci}$ turbulent air currents. In winter their numbers had also increased, especially about the numerous sawmills just north of the cultiviated areas. There they became quite tame, regularly visiting the garbage heaps, apparently with little to fear from the mill-workers, as guns or rifles were not usually permitted in bush camps or mills. Also it is said that a superstition prevails among many bush-workers that to kill a raven brings ill luck.

By 1953, ravens had become one of our more common winter birds, and at Nipawin they began to enter the town in search of garbage scraps or any other tidbit availiable. In numerous cases, pieces of bread or other food items are fed to the ravens by the citizens. One instance worthy of ncte: C.P.R. trainmen on an early morning train regularly threw out scraps for the ravens and as many as 40 ravens have been observed near the depot awaiting their breakfast. As many as a dozen or more have been seen at one time perched on telephone or power poles along
First Avenue, Nipawin's main thoroughfare. From the poles, they fly down to. the street in search of food, walking about and only reluctiantly moving out of the way of trafficpedestrians or cars.

Many amusing incidents could be told of the raven's adeptness at stealing food from dogs. To cite one instance of this: a raven boldily walked up to a dog chewing on a bone. After watching intently for a moment or two, the raven cleverly faked a peck at the bone several times, until the dog became so aggravated it suddenly made a rush for the bird which started as if to fly away, then turned a complete somersault and sniatched up the bone in full flight before the dog could recover from his headlong charge.

A pair of ravens have nested and reared their broods each year since 1953, in bulky nests built in the tops of huge black poplars growing from the bottom of a deep canyon near Nipawin. The nests are built of sticks, some of which are picked ur from the ground, and others (to the thickness of a man's finger) snapper off dead trees. They nest early-the three to five young have been observed to leave the nest as early as May 8. The parents are very solicitous in caring for their young anc have been observed as still attending and feeding them until as late as mid-August. This summer I observed two adult ravens stealing oatchop from a hog trough at the farm of Manley Peifer, three miles east of Nipawin, and carrying the food to four full-grown young, perched or a railing nearby.

Last March I saw a raven "dusting" in fine drifted snow, just as c barnyard fowl does in the dust ir summer. Crows sometimes gang up on ravens as they do on owls. Miaybe crows have a reason for this, as I have ciause to suspect the raven: of stealing crows' eggs and young and also the young and eggs of other birds. But all in all, the raven is a beautiful bird in the winter landscape, truly master of the air, anc an entertaining one with its seem. ingly unlimited repertoire of gurgle: and croaks and its curious habits May their numbers not diminish. 